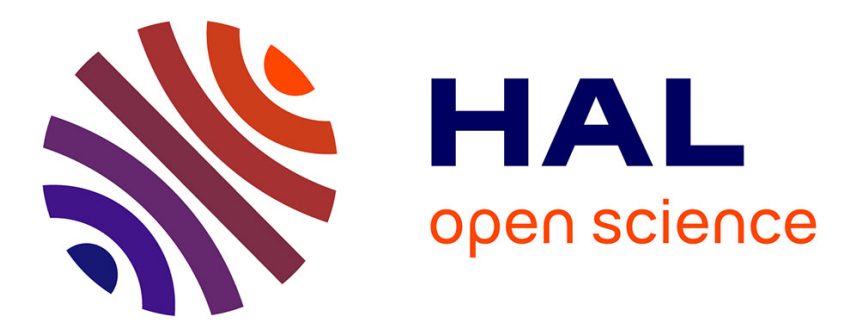

\title{
Understanding the cultural values at the individual level in central africa: A test of the cvscale in cameroon
}

\author{
Raoul Djamen, Laurent Georges, Jean-Louis Pernin
}

\section{To cite this version:}

Raoul Djamen, Laurent Georges, Jean-Louis Pernin. Understanding the cultural values at the individual level in central africa: A test of the cvscale in cameroon. International Journal of Marketing and Social Policy (IJMSP), In press, 10.17501/23621044.2019.2105 . hal-02866728

\section{HAL Id: hal-02866728 \\ https://univ-angers.hal.science/hal-02866728}

Submitted on 12 Jun 2020

HAL is a multi-disciplinary open access archive for the deposit and dissemination of scientific research documents, whether they are published or not. The documents may come from teaching and research institutions in France or abroad, or from public or private research centers.
L'archive ouverte pluridisciplinaire HAL, est destinée au dépôt et à la diffusion de documents scientifiques de niveau recherche, publiés ou non, émanant des établissements d'enseignement et de recherche français ou étrangers, des laboratoires publics ou privés. 


\section{UNDERSTANDING THE CULTURAL VALUES AT THE}

\section{INDIVIDUAL LEVEL IN CENTRAL AFRICA:}

\section{A TEST OF THE CVSCALE IN CAMEROON}

Raoul Djamen ${ }^{1}$, Laurent Georges ${ }^{2}$, Jean-Louis Pernin ${ }^{3}$

${ }^{1}$ Angers University, GRANEM EA 7456, Institute of the Gulf of Guinea, Douala,

Cameroon

raoul.djamenkouptoudji@etud.univ-angers.fr

${ }^{2}$ IUT Tarbes, Paul Sabatier University, LGCO - EA2043, Toulouse, France

laurent.georges@iut-tarbes.fr

${ }^{3}$ Paul Valery University, LERASS-CERIC, Montpellier France, jean.louis.pernin@iut-tarbes.fr 


\title{
UNDERSTANDING THE CULTURAL VALUES AT THE INDIVIDUAL LEVEL IN CENTRAL AFRICA: A TEST OF THE CVSCALE IN CAMEROON
}

\begin{abstract}
In order to reduce the risk of failure, it is vital to learn about the different cultures around the world before doing business in other countries. The existing crosscultural business literature dealing with culture assessment methods has been widely criticized (Sharma, 2010). For instance, most studies operationalize personal cultural orientations for individual consumers based on the national scores on Hofstede (1980, 1991) cultural dimensions. In response to these concerns, the Cultural Values Scale (CVSCALE) is a 26-item scale that has been developed by Yoo et al. (2011) to capture Hofstede's (1991) five cultural dimensions at the individual level. However, previous studies have not investigated these dimensions in Central Africa in general and specifically in Cameroon, a country which has many different ethnic groups. Therefore, the aim of this paper is to test the reliability and validity of the CVSCALE in Cameroon. The sample of this study is based on 550 managers working in a French or English speaking context and belonging to six different ethnic groups. Exploratory and confirmatory factor analyses are conducted by the authors. Results indicate that the CVSCALE exhibits appropriate reliability and validity. This study allows researchers and business practitioners to assess the cultural orientations of individuals and to use primary data instead of cultural stereotypes. As demonstrated, the CVSCALE is also very adequate to segment managers according to their individual cultural values.
\end{abstract}

Keywords: culture, values, cvscale, Cameroon, Hofstede 


\section{Introduction}

It is only a few decades since culture has come to business research and its importance is growing fast. The process of economic globalization has caused an expansion of research into international business and work related culture. De Mooij and Hofstede (2010) found focus on researching and investigating culture is becoming more popular. Looking at the expansion and influence of global firms, more and more international managers are becoming aware of the impact and importance of national culture on organizational culture. Thus adaptation and managing cultural diversity gradually brings change into both local and foreign companies (Morrison and Bergin-Seers, 2002). Nevertheless, the current business literature about culture measurement methods is rather chaotic (Yoo and Donthu, 2005). Because there is a lack of universally accepted scales, researchers have been using Hofstede's metrics (Sondergaard, 1994), which is one of the most frequently quoted frameworks. The influence of Hofstede's research has been significant in helping managers to understand characteristics of different cultures across different countries, revealing that each society may have different values concerning the nature of organizations. However, Hofstede's work was not out of criticism and problems. As argued by many authors (see for instance Yoo et al. 2011), it is designed for comparing national culture between different countries, and is not applicable to analyze culture influence on group at individual level.

To address these concerns, Yoo et al. (2011) committed their efforts to develop the CVSCALE - a tool for measuring Hofstede values scales at the individual level. Their work resulted in a 26-item questionnaire measuring the five dimensions of Hofstede's original model. They argued that such measurement is imperative because the use of national-level measures of culture overlooks the cultural values variability among individuals in the country (Yoo and 
Donthu, 2002) and the differences in the cultural values between age or ethnic groups in the same country. CVSCALE was successfully used and confirmed in such countries as USA, Brazil, Poland, Korea and Thailand (see Yoo et al. 2011). However, the scale was never tested in an African country and most of the research used samples of students.

In order to increase the strength of the CVSCALE - as well as its usefulness - the purpose of this article is to examine empirically the cultural values at the individual level in Cameroon, a country located Central Africa. Even though in 2050 , one fourth of the population will be in Africa, from a marketing point of view, little is known about African countries. In addition, rather than testing the scale among a population of students, the present research focuses on collecting data among a sample of business managers (junior, middle or senior levels). As such, this paper aims to help marketers and business executives to understand the characteristics of business managers' cultural values in Cameroon. First, business literature on culture is reviewed and the CVSCALE is presented in details. Second, strength of the CVSCALE is explored by analyzing results of exploratory and confirmatory factor analysis. Third, we examine managers' individual values in Cameroon and compare our results with those of other researchers. Finally, we demonstrate that the CVSCALE might be useful to segment managers according to their individual cultural values.

\section{Theoretical background}

\section{Hofstede's work on culture and its limits}

The globalization of markets and the diversification of consumer segments tend to increase the interest in the influence of culture on consumer behavior. Trompenaars and Hampden-Turner (1997) defined culture as "a shared system of meaning. It dictates what we pay attention to, how we act and what we value". For Hofstede, culture is the collective 
programming of the mind which distinguishes the members of one group from another. Culture in this sense, includes systems of values, and values are among the building blocks of cultures (Hofstede et al. 2010).

Over the last 30 years, Hofstede surveyed more than 116,000 IBM employees in over 40 different countries. The questions were about the participants' values and perceptions of their work situation. From the collected data, Hofstede discovered managers and employees are different on five value dimensions which are: individualism (IDV), masculinity (MAS), power distance (PDI), uncertainty avoidance (UAI) and long term-short term orientation (LTO) (Hofstede et al. 2010). As such, Hofstede's cultural framework provides a useful theoretical foundation to understand cross-cultural differences, and it has been popular for several reasons. First, Hofstede's framework is very comprehensive and shows meaningful relationships with important demographic, geographic, economic and political indicators of a society (Kale and Barnes, 1992). Second, Hofstede's works have been confirmed empirically through replications (e.g. Shackleton et al. 1990) and has been heavily cited as the most important and popular theory of culture types (Sondergaard, 1994). Third, it consistently proves to be beneficial when adopted in cross-cultural and international studies (e.g. Donthu and Yoo, 1998; Mattila, 1999; Furrer, Liu and Sudharshan, 2000; Patterson and Smith, 2001, 2003).

However, Hofstede's framework is designed for comparing national culture between different countries, and is not applicable to analyze culture influence on group or individual level. Moreover, Hofstede's $(1980,1991)$ measures were developed for work related environments. Therefore, as it is still a useful tool to explain differences in culture between countries, from a marketing point of view, it might be more useful to measure cultural values at the individual level. As stated by 
Yoo and Donthu (1999), using national generalizations to explain individual behaviors is an ecological fallacy, because country-level relationships are interpreted as if they were applied to individuals. In other words, looking at national culture and using that to individual consumers may not work. This concern is more accurate when a country consists of a heterogeneous population or ethnic groups with different cultural backgrounds. Such is the case for Cameroon where we can find more than 240 tribes and three main ethnic groups: Bantus, Semi-Bantus and Sudanese. The concept of national culture has been very useful for the study of nations and societies. However, in managerial situations, the reflection of culture at the individual level is more important and relevant (see Kamakura and Novak, 1992 as well as Kamakura and Mazzon, 1991).

In light of these critiques, several alternative frameworks have been proposed. Dorfman and Howell (1988) offered a 22 item measurement scale for analyzing the culture of a nation at the individual level. In the same vein, Sharma (2010) conceptualized personal cultural orientations as made of 10 dimensions. More recently, Yoo et al. (2011) committed their effort to develop CVSCALE - a tool for measuring Hofstede's values scales at individual level. CVSCALE was successfully used and confirmed in such countries as USA, Brazil, Poland, Korea and Thailand (see Yoo et al,. 2011). CVSCALE can be used to compare individual scales both inside nation and in international or cross-cultural comparisons.

\section{CVSCALE as an alternative framework}

The CVSCALE was used to examine the cultural values of individualism/collectivism, masculinity/femininity, power distance and uncertainty avoidance. The other cultural dimension, known as Confucian dynamism, is long-term orientation. Below is a short definition for each dimension:

- Power distance: the degree to which power in equality is distributed among the society's members and what the 
consequences of power inequality and authority relation in society are. It is based on the value systems of less powerful members and explained from the behavior of the more powerful leaders (Hofstede and al., 2010). In high power distance societies, everyone has his/her rightful place in hierarchy; as a result it will be accepted by others whereas in low power distance cultures authority is not as important as equality and opportunities (De Mooij and Hofstede, 2011).

- Uncertainty avoidance: the degree to which organizational members perceive risks from uncertain situations or future uncertainty (De Mooij and Hofstede, 2011). To cope with ambiguity, people in strong uncertainty avoidance societies try to make rules. Paradoxically, it deals with risk taking and the rule of laws for prescribed behavior; anxious people are often prepared to adopt some risky behaviors in order to reduce the uncertainty (Hofstede and al., 2010).
- Individualism and collectivism: the explanation of the link between the individual and the collective whole that is revealed in the way people live within the society. Whereas in a collectivistic culture, people are "We" conscious; group or family comes first. Individuals are willing to sacrifice their immediate wishes for the sake of family (De Mooij and Hofstede, 2011). In collectivistic culture, there is no individual success and the group look after you in exchange for loyalty (Hofstede and al., 2010).

- Masculinity and femininity: in a dominant society, culture favors competition and success, achievement and control. Men are supposed to be assertive, tough and focused on material success whereas in feminine society, for both male and female, the dominant values are caring and nurturing for others, concerned for safety and quality of life where men and women are equal (Hofstede and al., 2010).

- Long Term-Short Term orientation:

"Long-term orientation stands for the 
fostering of virtues oriented toward future

rewards-in particular, perseverance and

thrift. Its opposite pole, short-term orientation, stands for the fostering of virtues related to the past and present in particular, respect for tradition, preservation of "face" and fulfilling social obligations" (Hofstede et al., 2010, p. 239). It's a degree to which people feel about traditional values, the truth and perseverance. Whether people are ready to give up present fun for a better future (long term oriented) or they value tradition. For them, past and present are important and individuals do not see commitments as obstacles. They are willing to spend whatever they have now, and future is less important (De Mooij and Hofstede, 2011). The majority of the 26 CVSCALE's items are modified versions of Hofstede's original scale items that reflect non-work related situations (Sobol, 2008). We chose CVSCALE as some researchers reported the lack of reliability and validity of Hofstede's scale (Bearden et al., 2006). On the other hand, the CVSCALE has good reliability, validity and cross-cultural invariance (Patterson et al., 2006). Moreover, the items are advantageous over Hofstede's (2001) items as the instrument applies to general consumer situations, as opposed to limited situations. The dimensions and items utilized in this study are presented in Table 1.

Table 1 about here

\section{Methodology}

\section{Questionnaire development and measures}

As all the constructs used in our research were based on studies carried out in English-speaking countries, the questionnaire was originally developed in English. Following Brislin's recommendations, this was translated into French by an expert professional translator. Then, a second bilingual blindly translated the material back into English. Finally, 
under the supervision of the research team, both translators reconciled any differences. At this point, to assess face validity, three experts, all university professors in marketing, reviewed the measures in cooperation with the first author to make a preliminary judgment about the quality of the translation. To refine the wording of items, the questionnaire was pre-tested on ten French graduate students. Based on their comments some minor modifications were made.

To measure the dimension of cultural values, the Scale of Individual Cultural Values was used (CVSCALE; Yoo et al., 2011). As explained earlier, CVSCALE consists of five dimensions of cultural values as expressed by Hofstede et al. (2010), but the measurement was conducted within the individual level. The cultural orientation items were evaluated using 5point Likert-type scales anchored as $1=$ "very unimportant" and 5= "very important" for the long-term orientation dimension, and $1=$ "strongly disagree" and
$5=$ "strongly agree" for the remaining dimensions.

\section{Data collection procedure and samples}

The sampling frame for this study is business managers (low, middle and top levels) in two cities of Cameroon (Douala and Yaoundé). All of them have been contacted for data collection through convenience sampling techniques. Overall, 550 self-report questionnaires were collected, but since 22 had to be eliminated because they were not complete, 528 usable questionnaires were obtained. These represented full-time employees who chose to participate from 92 private and government organizations, registered in Cameroon. These organizations were identified through two sources. The first source consisted of a list of organizations maintained by the Chamber of Commerce. The second one was provided by University Institute of the Gulf of Guinea. As suggested by Smith and Schwartz (1997), to ensure that the differences obtained are due to cultural, as opposed to demographic 
differences, cross-cultural researchers are recommended to use people from a similar demographic background. The demographic profile of Cameroon is complex for a country because of its population. Cameroon comprises an estimated 250 distinct ethnic groups, which may be formed into six large regionalcultural divisions. Table 2 shows the Cameroon population and the sample breakdown by ethnic groups, and demonstrates that the quota sample obtained is reasonably representative of the Cameroon population. Gender distribution was relatively even although the male respondents were somewhat more represented than their female counterparts. Additionally, the literacy level of the respondents is not in doubt going by the percentage of literate people. Thus, the quality of the responses obtained is confirmed. In terms of respondents' occupation, nearly $22 \%$ were employed by the government whereas more than $78 \%$ were employed by private organizations.
Finally the distribution of respondents' ethnicity was relatively similar to the distribution obtained from Cameroon Official Census Data.

The data proved suitable to undergo factor analysis through three means. Firstly, sample size met the requirement of a ratio of five responses per one item (DeVellis, 2012; Tinsley and Tinsley, 1987). Secondly, the Kaiser-Meyer-Olkin (KMO) measure of sample adequacy measured 0.80 , well exceeding the score of 0.60 , which serves to indicate a sufficient sample size (Hair et al., 1998). Thirdly, Bartlett's test proved significant $(\mathrm{p}=.000)$, providing additional confirmation of the appropriateness for conducting factor analysis.

Table 2 about here

\section{CVSCALE analysis and results}

Following standard procedures for developing psychometrically sound 
measures (Churchill, 1979), several steps

were taken to ensure the reliability and validity of the multi-items scales. The first step included analyzing for correlations and suitability for factor analysis. A one-way analysis of variance (ANOVA) followed next to assess the influence of each of the demographic factors (age, gender, language, level of education, organization size, organization status, level of education and ethnicity) on the principal components. The analysis included: (a) scale reliability using Cronbach's $\alpha$, (b) exploratory factor analysis using the principal component method, and (c) confirmatory factor analysis using the maximum likelihood method.

\section{Reliability}

Scale reliability was assessed in terms of item-to-total correlation and Cronbach's Alpha to determine the discriminative power and internal consistency of the scale (Peter, 1979). For each of the 5 dimensions of the scale, a Cronbach's was computed (using SPSS) to test the reliability. As indicated in Table 2, for power distance the reliability was $.71, .77$ for uncertainty avoidance, .63 for collectivism, .77 for masculinity, and .80 for long-term oriented. Thus, the measurement scale achieved satisfactory levels of reliability as all items yield value more than .60 (Nunnally and Bernstein, 1994).

\section{Exploratory Factor Analysis (EFA)}

The next step included subjecting the 26 items of the CVSCALE to a principal components factor analysis using SPSS version 23 . In order to determine how many factors required extraction, the process included conducting three examinations of the data and then comparing the results using eigenvalues, scree plots, and the pattern matrix. As shown in Table 3, five factors with eigenvalues over 1.0 (2.32 for power distance, 2.58 for uncertainty avoidance, 2.43 for collectivism, 2.71 for masculinity, and 3.10 for long-term oriented), together account for $51.57 \%$ of variance, with the first factor accounting for $18.23 \%$ of that variance. This result is 
similar to Prasongsukarn (2009) test of the

CVSCALE in Thailand in which $54.9 \%$ of the variance was explained as well as to Yoo and al. (2011) in which $44.5 \%$ of the total variance was explained for the pooled data $(49 \%$ for Americans, $47.9 \%$ for Korean-American, and 40.7\% for Koreans). In the same vein, but at a country-level, Hofstede (1980) found $49 \%$ of the total variance explained. Table 3 shows the first 10 factors.

The final consideration for determining the appropriate number of factors to extract involved examining the pattern matrix, as presented in Table 4 . The pattern matrix for the five-factor model, using an orthogonal (Varimax) rotation, reveals clusters of three or more highly rated items $(>0.5)$. Factor analysis using oblique (Oblimin) rotation produced similar factor patterns, confirming the discriminant and convergent validity of the measures (Rummel, 1970).

Tables 3 and 4 about here

\section{Confirmatory Factor Analysis (CFA)}

We conducted confirmatory factor analysis to detect and confirm the clear multidimensionality of the five cultural dimensions as asserted by Hofstede. A completely standardized solution produced by the AMOS 20 maximum likelihood method (Jöreskog and Sörbom, 1993) showed that all items loaded on their corresponding constructs. Demonstrating adequate convergent validity of all items, the lowest t-value was 12.22 for LT3 on long-term orientation. Also, the overall fit of the measurement model was very good: CMIN/DF: 1.623, GFI (goodness-of fit index): 0.936, AGFI (adjusted goodness of fit index): 0.922, CFI (comparative fit index): 0.952, RMSEA (root mean square error of approximation): 0.034 (0.0290.040). These results are similar to those of Yoo and al. (2011) and of Prasongsukarn (2009). All items show significance of more than .001 on all dimensions. The average 
variance extracted for each dimension was

only moderate for COL (.23), but satisfactory for INC (.49) and POW (.66) and excellent for LST (.86) and for MAS (.97); all are greater than the squared correlation between the dimension and any other dimension, which indicates the independence (divergent validity) of the dimensions (Fornell and Larcker 1981). Figure 1 presents the confirmatory factor analysis (CFA) model of the CVSCALE.

Figure 1 about here

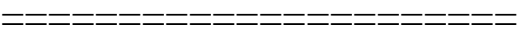

Power distance: the total mean of the five items was $2.9 / 5=.58$ which suggests a difference from the other African countries. At .58 Cameroon has an intermediate score, but it indicates a slight tendency to the higher side of PDI - i.e. managers believe hierarchy should be respected and inequalities amongst people are acceptable. The different distribution of power justifies the fact that power holders have more benefits than the less powerful in society. In Cameroon, it is important to show respect to the elders (and children take care for their elderly parents). In companies, there is one boss who takes complete responsibility. Status symbols of power (cars, watches) are Managers' cultural values at the individual level in Cameroon very important in order to indicate social position.

Uncertainty avoidance: the total mean of the 5 items is $4 / 5=.80$. It is a high score indicating, (as for the other African countries), a preference for avoiding uncertainty. In these cultures, there is an emotional need for rules. Managers in Cameroon are not at all comfortable in 
ambiguous situations. In Cameroon, as in all high uncertainty avoidance societies, bureaucracy, laws and rules are very important to make business safer. They don't like surprises and structure and planning are often required. This, however, doesn't mean that most managers in Cameroon will try to follow all these rules. Given the moderately high score on Power Distance (which means that power holders have privileges), power holders don't necessarily feel obliged to follow all those rules (which are meant to control the average individual).

Individualism and collectivism: African societies are generally considered as collectivistic. Loyalty is paramount and overrides most other societal rules and regulations. The society fosters strong relationships where everyone takes responsibility for fellow members of their group. With a moderately low score of 42 , managers in Cameroon partly share this collectivist orientation. However, several collectivistic traits still prevail among managers: for instance, the opinion of and obligations towards the extended family. This notwithstanding, as indicated by our data, more modern, individualist traits can also be found, particularly among managers who are confronted to the competitive world of business and educated in business schools in Europe or in the United States. Masculinity and femininity: the overall mean of this dimension was $3.48 / 5=.70$, a score much higher than the one of the other African societies. According to Hofstede, it indicates that the society is driven by competition, achievement and success, with success being defined by the winner / best in field - a value system that starts in school and continues throughout organizational life. As we only interviewed managers, this result is not surprising. By nature, the corporate world is competitive and performance is the key in many companies. Managers in Cameroon (as in many other societies) will not hesitate to sacrifice leisure priorities to work. In Cameroon large cities (such as Douala or Yaoundé) 
service and retail people will work until very late at night and retail businesses are open during weekends.

Long-term orientation / short-term orientation: the overall mean of the longterm orientation was $4.14 / 6=.69$, a higher score in comparison with the other African countries. Normative societies which score low on this dimension prefer to maintain traditions and norms while viewing societal change with suspicion. Those with a culture which scores high take a more pragmatic approach and encourage thrift and efforts in modern education as a way to prepare for the future. With a score of 0.9, Cameroon's managers can be viewed as pragmatic. Thanks to their education and due to their confrontation with the ever changing business world, they probably show a better ability to adapt traditions to situations. In comparison with the average population, they also have a stronger propensity to save and invest money (i.e. thriftiness).
Table 5 about here

\section{Cultural values in Cameroon according to the individuals' characteristics}

Since the cross-cultural literature suggests that age and gender may affect measures of cultural orientations (Lenartowicz and Roth, 1999), we tested these variables (as well as ethnicity and language) for their confounding influence. Data analysis indicated a significant correlation between age and collectivism $(\mathrm{p}<.005)$, masculinity and long-term orientation $\quad(\mathrm{p}<.001)$. Hofstede (2001) also reported a similar significant gender effect on masculinity. With no surprise, we also noted a significant effect of gender on masculinity $(\mathrm{p}<.001)$. Gender has no significant effect on the other dimensions of the CVSCALE. Regarding the influence of language, we noted a significant effect on masculinity and power distance $(\mathrm{p}<.001)$. In comparison with the English speaking managers, French speaking managers scored higher on the 
masculinity dimension but lower on the power distance dimension. It also appears that the level of education has a significant effect on long-term orientation and uncertainty avoidance $(\mathrm{p}<.001)$. The higher the level of education, the higher the longterm orientation and the lower the uncertainty avoidance.

One-way ANOVA also demonstrated a significant $(p<.001)$ ethnicity effect on all the dimensions of the CVSCALE. In other words, cultural values vary according to ethnic groups. Table 6 reports the average, standard deviation and $\mathrm{F}$ value for the CVSCALE dimensions according the three main ethnic groups ${ }^{1}$. These results indicate clearly that when doing business in Cameroon, identifying the ethnic group of the business partner is key, as cultural values will vary accordingly. Three distinct profiles emerged from the data, as well as a clear distinction between the ethnic groups. Bamiléké and Bamoun managers are characterized by a medium level

\footnotetext{
${ }^{1}$ The other ethnic groups present in our sample were not selected because of a low number of respondents.
}

collectivism, medium masculinity, small power distance, and a high level of longterm orientation and uncertainty avoidance. The second ethnic group includes Douala, Lundu and Bassa. It is characterized by low scores on masculinity and power distance, higher collectivism, mild uncertainty avoidance and high long-term orientation. Fang and Beti make up the final ethnic group. It exhibits the highest scores on power distance and masculinity and the lowest scores on the uncertainty avoidance and long-term orientation dimensions. It also depicts medium-low collectivism.

Table 6 about here

Given the limited size of our sample and, the fact that these results tend to stereotype the different ethnic groups, caution should be taken in their interpretation. Nonetheless, they can be of help for 
international marketers and salespersons doing business in Cameroon. For instance, it appears that Bamiléké and Bamoun managers will tend to follow procedures and instructions. They will also expect clear instructions from their partners or hierarchy. In addition, it could be argued that they will tend to favor long term relationships based on cooperation and commitment. As they score low on power distance, they will accept to meet and negotiate with people in lower positions. Fang and Beti are characterized by a very different profile. Uncertainty is not an issue and, they will not look for long-term planning. Thus, their favored selling/buying strategy might be more transactional and short term, and less cooperative (in comparison with the two other ethnic groups). As these managers score high on power distance and masculinity, matching status and gender might be of paramount importance when negotiating with them. Finally, Douala, Lundu and Bassa managers share some similarities with the Bamiléké and Bamoun, especially regarding longterm orientation and uncertainty avoidance. Thus, developing long term relationships based on trust and commitment (rather than short-term relationships based on competition), should be encouraged. As it is the ethnic group with the highest score on collectivism, group success is of key importance when doing business with these managers. Hence, team work and suppliercustomer collaboration should be developed.

\section{Usage of the CVSCALE: segmenting}

\section{managers with cultural values}

In promoting their products or services, marketers look for a common and positive answer from the targeted consumers. This intended response is a function of what the marketing stimulus "means" to the consumer and, similarity in culture should translate into similarity in meaning and, buyer response (Kale, 1995). Therefore, global marketers usually group individuals into market segments according to their country of origin, by using Hofstede's 
national-culture indices (see for instance Kale, 1995). Then, marketing plans are formulated and implemented to equally target all the individuals of the countries within the segment. In the same vein, in business-to-business markets, salespersons tend to adapt their negotiation strategies or selling technics according to the culture of the buyers. Yoo, Donthu and Lenartowicz (2011) argued that when segmenting consumers, individual-centered market segmentation can be more useful and meaningful than can countries or geographic centered segmentation. To illustrate their argument and the usefulness of the CVSCALE, we conducted a two-step cluster analysis through SPSS 23. We selected the three main ethnic groups represented in our study: Bamiléké and Bamoun $(n=146)$, Fangs or Beti $(n=111)$ and Douala, Lundu or Bassa $(\mathrm{n}=129)$, whose data where used for scale validation. As segmentation variables, we used the five dimensions of CVSCALE and a three cluster solution was found optimal with a

ratio of sizes (largest cluster to smallest cluster) of 2, which is satisfactory. The predictors (i.e. dimensions of the CVSCALE) importance ranked as followed: long-term orientation (1.00), power distance (0.68), uncertainty avoidance (0.58), masculinity (0.26) and, collectivism (0.10). As reported in the top of Table 7, the average CVSCALE score profiles showed that Segment 1 was higher in long-term orientation and uncertainty avoidance. Segment 2 maintained the lowest mean value in every dimension except for power distance and masculinity. Segment 3 is characterized by higher collectivism and lower power distance. As shown previously (see Table 6), CVSCALE mean differences among the ethnic groups are significant. Thus, these results indicate a clear division among the segments and the usefulness of CVSCALE for segmentation.

Table 7 about here 
Overall, Segment 1 might be labeled "relational managers, individuals with uncertainty avoidance and long-term orientations". Segment 2 might be labeled "transactional managers, people with a short-term orientation looking for power maximization”. Segment 3 can be depicted as "collaborative managers, team players, individuals favoring the group success (rather than individual goals) and, a peaceful orientation characterized by low power maximization and masculinity". As reported at the bottom of Table 7, slightly more than half of Bamiléké and Bamoun (58\%) belonged to Segment 1, whereas Fang and Beti belonged to Segment 2, and Douala, Loundou and Bassa to Segment 3. Thus, the derived clusters showed a clearcut match to the ethnic groups. Regarding language, French and English speakers were divided almost equally across Segments 1 and 2. By contrast, Segment 3 is characterized by a very high percentage of French speakers. Finally, the highest ratio of male subjects is associated with
Segment 2. It is also the segment where we can find the highest score on masculinity and power distance. This result could have been expected.

\section{Discussion}

The purpose of this study was to investigate the cultural values of business managers in Cameroon, a country located in Central Africa. Understanding the cultural context is mandatory to reduce the risk of failure when doing business abroad. To overcome major weaknesses of past studies, and because Cameroon is a heterogeneous society composed of many ethnic groups, the authors used CVSCALE, a 26-item five dimensional scale developed by Yoo et al. (2011) to measure cultural values at the individual level.

\section{Theoretical Implications}

As argued by Soares and al. (2007), further cross-cultural research should examine the CVSCALE's reliability and validity in additional countries and research contexts 
beyond those studies by Donthu and Yoo (1998) and Soares (2005). From a theoretical standpoint, results of our study indicate that the CVSCALE exhibits appropriate reliability and validity, thus confirming prior studies (see Yoo et al., 2011 for a review). From a marketing point of view, little is known about African countries, consumers and managers. As an initial study that focuses on managers' cultural values in Cameroon, the theoretical contribution of this study seems quite promising and may be developed and strengthened in the future. Rather than using students or consumers samples as in existing marketing research on culture, we used a sample of business managers in Cameroon. Our results demonstrated significant differences with Hofstede's findings in other African countries. One possible explanation is that the CVSCALE measures cultural values at the individual level and not at the national level, thus not equating individual culture to the national one. Perhaps more importantly, this study showed that - as Cameroon is a very diverse cultural country, comprising more than 250 ethnic groups - identifying one common national culture might be difficult. Therefore, from a theoretical point of view, blindly looking at national culture and using that to individual consumers or managers may not work, especially in countries composed of several ethnic groups. The surveyed managers do not share a unique language, belong to different ethnic groups and are employed by private or government organizations. Nevertheless, the 26-item five-dimensional CVSCALE achieved satisfactory psychometric properties and the confirmatory measurement demonstrated a good fit. It confirmed the reliability and construct validity of the five-factor model of CVSCALE within a diverse cultural country like Cameroon, which increased the generalizability of the CVSCALE. As an emerging area of research, thrilling for increasingly globalized organizations, this serves as a significant step forward that may further encourage empirical research. 
success is more important than individual

\section{Managerial and social implications}

Cultural understanding is a key issue facing multinational firms. There are three main implications of our findings.

First, from a human resource development perspective our results provide useful insights on the managers' cultural values in Cameroon. When opening a branch in Cameroon, foreign companies should take these aspects into consideration; especially the fact that individual cultural values are different among the ethnic groups. Hence, managers sent to Cameroon for foreign/overseas assignments should be made familiar with the basic knowledge about ethnic groups' culture. Such programs are important to develop interpersonal skills and to deal with unfamiliar cross-cultural situations. For instance, our study clearly indicates that Bamiléké and Douala tend to avoid uncertainty and are more long-term oriented than Fangs. In addition, for them, group goals.

Second, as demonstrated in the analysis of three-ethnic group data, CVSCALE is very adequate for market segmentation. The three identified segments of managers clearly differ. In a business-to-business context, a better understanding of the cultural context might help in reducing cultural distances and strengthening business-to-business relationships. For instance, our results indicate that when dealing with managers belonging to the Bamiléké and Douala ethnic groups, it seems more appropriate to develop a long term relationship (than a short-term one). Collaboration, as well as programs and procedures aiming at reducing uncertainty, should also be strengthened. By contrast, when dealing with Fang or Beti counterparts, a more transactional or shortterm orientation should be favorised. As these managers will tend to maximize their power, distributive (rather than integrative) 
bargaining strategies might be more appropriate.

Third, the finding of this study has also social implications. CVSCALE provides insight into cross-cultural situations and increases the ability of managers but also people, in general, to better understand foreign cultures. Such "cultural intelligence" has been linked to job performance (see for instance, Jyoti and Kour 2017) as culturally intelligent managers are able to interact with people belonging to different cultures, regions or religions and, thus, are in a better position to build relationships and reinforce trust. Understanding each other's culture, values, beliefs and rules create the feeling of unity in society.

We do not intend to argue that using a few dimensions provides a complete description of cultural differences that exist between the many ethnic groups in Cameroon. However, we argue that the CVSCALE constitutes a simple, practical, and usable shortcut to a better understanding of individual cultural differences among managers.

\section{Limitations and Outlook}

This study has certain limitations, which shall be kept in mind. Firstly, the external validity of our research is limited as we only interviewed managers in Cameroon. Moreover, we did not test the nomological validity of the CVSCALE. However, it should be noted, that in previous research dealing with the development and validation of the CVSCALE, these two forms of validity had been tested. For instance, Yoo, Donthu and Lenartowicz (2011) investigated the relationship of the CVSCALE individual dimensions to two constructs: consumer ethnocentrism and attitudes toward marketing norms. Several studies (Donthu and Yoo, 1998; Paul et al., 2006; Patterson et al., 2006; Smith, 2004) also demonstrated its reliability in different countries and, thus the cross-national generalizability of the scale. Secondly, even though, the sample size of this research met 
the requirements, a larger sample would enhance validity. Specifically, a more ethnically diverse sample from a large number of organizations would prove valuable. Thirdly, as demonstrated in the analysis of three-ethnic group data, CVSCALE is adequate for segmenting managers showing diverse cultural orientations. Such groupings are valuable as companies can then develop business strategies adapted to each segment. However, it should be underlined that in addition to individual cultural values, other variables - such as organizational culture, technology, level of specific assets, and so on - will influence managers' buying or selling strategy. Additional research would then prove valuable in order to ascertain the impact of the CVSCALE dimensions on the salespersons and buyers' behaviors. For instance, a productive start will be to see if a preferred bargaining or conflict management strategy could be associated with each of the three segments identified in our study.

Although the scale was already adopted and proved useful by researchers for many countries, future studies need to keep validating CVSCALE using larger and demographically diverse samples as well as respondents from other African countries. Additional research may also provide more useful insights on individual values by conducting qualitative investigations to better understand various aspects of culture. As some probability exists that not all elements of culture at the individual level were captured by the CVSCALE, additional items and dimensions might also prove valuable in improving the existing instrument. 
Figure 1: Confirmatory factor analysis results

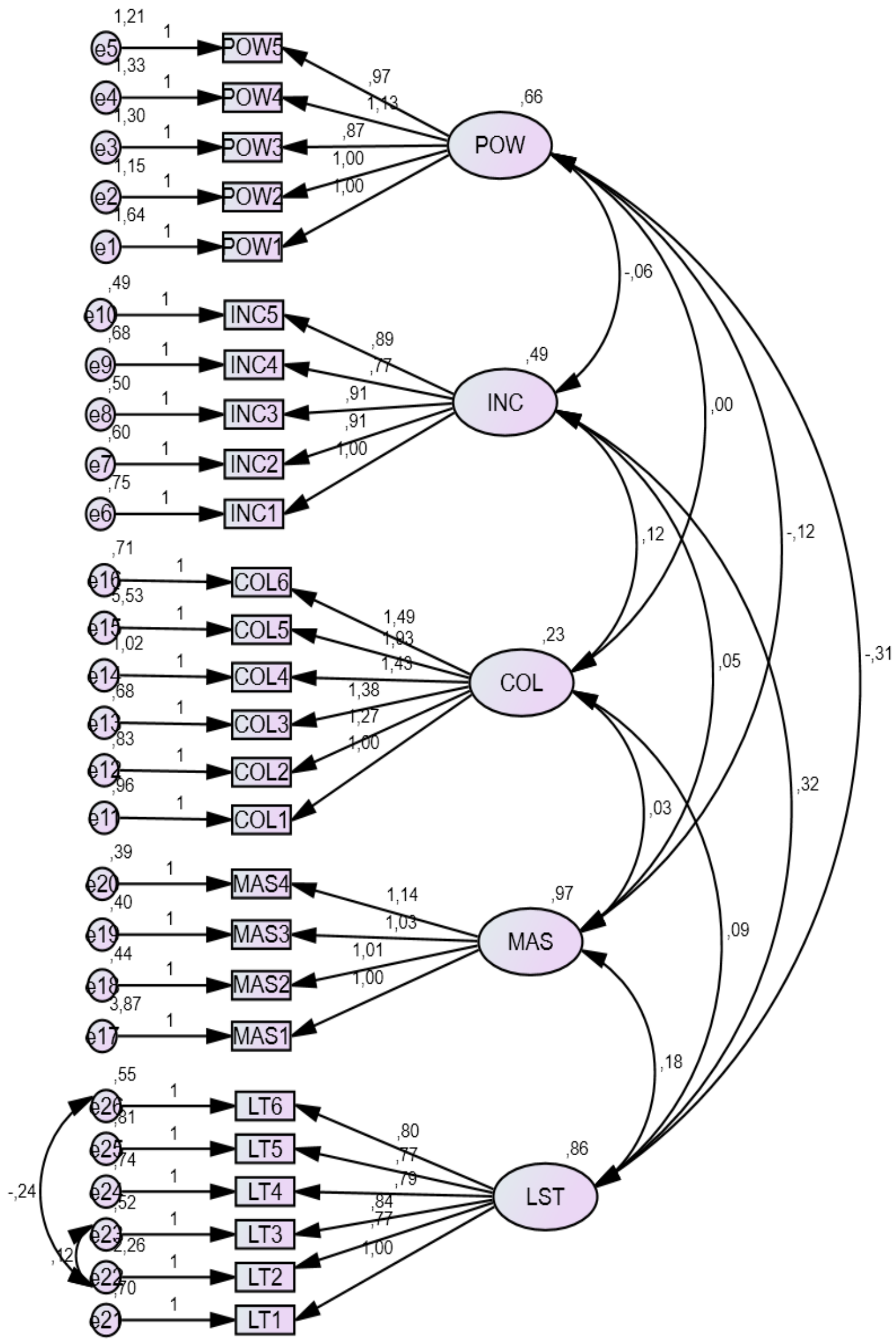


Table 1: CVSCALE, taken from Yoo, Donthu and Lenartowicz, (2011)

\begin{tabular}{|c|c|}
\hline \multicolumn{2}{|r|}{ Power distance } \\
\hline POW1 & $\begin{array}{l}\text { People in higher positions should make most decisions without consulting } \\
\text { people in lower positions. }\end{array}$ \\
\hline POW2 & $\begin{array}{l}\text { People in higher positions should not ask the opinions of people in lower } \\
\text { positions too frequently. }\end{array}$ \\
\hline POW3 & $\begin{array}{l}\text { People in higher positions should avoid social interaction with people in lower } \\
\text { positions. }\end{array}$ \\
\hline POW4 & $\begin{array}{l}\text { People in lower positions should not disagree with decisions by people in higher } \\
\text { positions. }\end{array}$ \\
\hline POW5 & $\begin{array}{l}\text { People in higher positions should not delegate important tasks to people in } \\
\text { lower positions. }\end{array}$ \\
\hline \multicolumn{2}{|r|}{ Uncertainty avoidance } \\
\hline UNC1 & $\begin{array}{l}\text { It is important to have instructions spelled out in detail so that I always know } \\
\text { what I'm expected to do. }\end{array}$ \\
\hline UNC2 & It is important to closely follow instructions and procedures. \\
\hline UNC3 & $\begin{array}{l}\text { Rules and regulations are important because they inform me of what is expected } \\
\text { of me. }\end{array}$ \\
\hline UNC4 & Standardized work procedures are helpful. \\
\hline UNC5 & Instructions for operations are important. \\
\hline \multicolumn{2}{|r|}{ Collectivism } \\
\hline COL1 & Individuals should sacrifice self-interest for the group. \\
\hline COL2 & Individuals should stick with the group even through difficulties. \\
\hline COL3 & Group welfare is more important than individual rewards. \\
\hline COL4 & Group success is more important than individual success. \\
\hline COL5 & $\begin{array}{l}\text { Individuals should only pursue their goals after considering the welfare of their } \\
\text { group. }\end{array}$ \\
\hline COL6 & Group loyalty should be encouraged even if individual goals suffer. \\
\hline \multicolumn{2}{|r|}{ Masculinity } \\
\hline MAS1 & It is more important for men to have a professional career than it is for women. \\
\hline MAS2 & It is more important for men to have a professional career than it is for women. \\
\hline MAS3 & It is more important for men to have a professional career than it is for women. \\
\hline MAS4 & It is more important for men to have a professional career than it is for women. \\
\hline \multicolumn{2}{|r|}{ Long term orientation } \\
\hline LT1 & Careful management of money (Thrift) \\
\hline LT2 & Going on resolutely in spite of opposition (Persistence) \\
\hline LT3 & Personal steadiness and stability \\
\hline LT4 & Long-term planning \\
\hline LT5 & Giving up today's fun for success in the future \\
\hline LT6 & Working hard for success in the future \\
\hline
\end{tabular}


Table 2: Description of the sample

\begin{tabular}{|c|c|c|}
\hline & $\begin{array}{l}\text { Sample } \\
(\mathrm{n}=528)\end{array}$ & $\begin{array}{c}\text { Cameroon } \\
\text { (INSC census data) }\end{array}$ \\
\hline \multicolumn{3}{|l|}{ Gender } \\
\hline Male & $301(57 \%)$ & $49.9 \%$ \\
\hline Female & $227(43 \%)$ & $50.1 \%$ \\
\hline \multicolumn{3}{|l|}{ Spoken language } \\
\hline French & $332(62.9 \%)$ & $83 \%$ \\
\hline English & $196(37.1 \%)$ & $17 \%$ \\
\hline \multicolumn{3}{|l|}{ Management level } \\
\hline Top-level & $40(7.6 \%)$ & N/A* \\
\hline Middle-level & $189(35.8 \%)$ & $\mathrm{N} / \mathrm{A}$ \\
\hline Low-level & $299(56.6 \%)$ & N/A \\
\hline \multicolumn{3}{|l|}{ Age } \\
\hline Below 20 & $6(1.2 \%)$ & $54 \%$ \\
\hline 20 to 40 & $409(77.4 \%)$ & $28 \%$ \\
\hline Above 40 & $113(21.4 \%)$ & $18 \%$ \\
\hline \multicolumn{3}{|l|}{$\begin{array}{l}\text { Education } \\
\end{array}$} \\
\hline Less than high school & $53(10 \%)$ & N/A \\
\hline High school degree & $144(27.3 \%)$ & N/A \\
\hline College degree & $331(62.7 \%)$ & N/A \\
\hline \multicolumn{3}{|l|}{ Ethnicity } \\
\hline Bamilékés and Bamouns & $140(26.5 \%)$ & $24.5 \%$ \\
\hline Douala, Lundu and Bassa & $127(24 \%)$ & $14.7 \%$ \\
\hline Fangs or Beti & $107(20.2 \%)$ & $18.6 \%$ \\
\hline Peuls & $51(9.6 \%)$ & $9.6 \%$ \\
\hline Tikar & $19(3.7 \%)$ & $3.4 \%$ \\
\hline $\begin{array}{l}\text { Others (Mandara, Haoussas, Maka, } \\
\text { Chamba and Mboum) }\end{array}$ & $84(15.9 \%)$ & $15.5 \%$ \\
\hline \multicolumn{3}{|l|}{ Number of years in organization } \\
\hline Less than 1 year & $76(14.4 \%)$ & N/A \\
\hline $2-5$ years & $67(12.7 \%)$ & N/A \\
\hline $6-10$ years & $210(39.8 \%)$ & N/A \\
\hline $11-15$ years & $89(16.8 \%)$ & N/A \\
\hline $16-20$ years & $63(11.9 \%)$ & N/A \\
\hline More than 20 years & $23(4.4 \%)$ & N/A \\
\hline \multicolumn{3}{|l|}{ Organization status } \\
\hline Working in private organization & $78.8 \%(411)$ & N/A \\
\hline Working in government organization & $21.2 \%(117)$ & N/A \\
\hline \multicolumn{3}{|l|}{ Number of full-time employees } \\
\hline Less than 10 & $28(5.3 \%)$ & N/A \\
\hline $10-50$ & $32(6 \%)$ & N/A \\
\hline $51-99$ & $178(33.7 \%)$ & N/A \\
\hline $100-249$ & $157(29.7 \%)$ & N/A \\
\hline $250-999$ & $75(14.3 \%)$ & N/A \\
\hline More than 1000 & $58(11 \%)$ & N/A \\
\hline
\end{tabular}

* Data not available from INSC official census data 
Table 3: Total variance explained (exploratory factor analysis)

\begin{tabular}{|c|c|c|c|c|c|c|c|}
\hline & \multicolumn{3}{|c|}{ Initial eigenvalues } & \multicolumn{3}{c|}{$\begin{array}{c}\text { Extraction sums of } \\
\text { squared loadings }\end{array}$} & $\begin{array}{c}\text { Rotation sums of } \\
\text { squared loadings }\end{array}$ \\
\hline Component & Total & $\begin{array}{c}\text { \% of } \\
\text { variance }\end{array}$ & $\begin{array}{c}\text { Cum. } \\
\%\end{array}$ & Total & $\begin{array}{c}\% \text { of } \\
\text { variance }\end{array}$ & $\begin{array}{c}\text { Cum. } \\
\%\end{array}$ & Total \\
\hline 1 & 4.74 & 18.23 & 18.23 & 4.74 & 18.23 & 18.23 & 3.83 \\
\hline 2 & 2.82 & 10.83 & 29.07 & 2.82 & 10.83 & 29.07 & 2.67 \\
\hline 3 & 2.44 & 9.38 & 38.45 & 2.44 & 9.38 & 38.45 & 2.86 \\
\hline 4 & 1.90 & 7.32 & 45.77 & 1.90 & 7.32 & 45.77 & 2.65 \\
\hline 5 & 1.50 & 5.80 & 51.57 & 1.51 & 5.80 & 51.57 & 3.21 \\
\hline 6 & 0.99 & 3.82 & 55.38 & & & & \\
\hline 7 & 0.94 & 3.60 & 58.98 & & & & \\
\hline 8 & 0.89 & 3.44 & 62.41 & & & & \\
\hline 9 & 0.81 & 3.11 & 65.53 & & & & \\
\hline 10 & 0.77 & 2.95 & 68.48 & & & & \\
\hline
\end{tabular}

Table 4: Pattern matrix (exploratory factor analysis)

\begin{tabular}{|c|c|c|c|c|c|}
\hline & \multicolumn{5}{|c|}{ Components } \\
\hline Item & 1 & 2 & 3 & 4 & 5 \\
\hline LT3 & 0.79 & & & & \\
\hline LT1 & 0.73 & & & & \\
\hline LT4 & 0.72 & & & & \\
\hline LT5 & 0.71 & & & & \\
\hline LT6 & 0.71 & & & & \\
\hline LT2 & 0.53 & & & & \\
\hline POW1 & & 0.69 & & & \\
\hline POW4 & & 0.69 & & & \\
\hline POW2 & & 0.67 & & & \\
\hline POW3 & & 0.66 & & & \\
\hline POW5 & & 0.63 & & & \\
\hline MAS1 & & & 0.60 & & \\
\hline MAS3 & & & 0.89 & & \\
\hline MAS2 & & & 0.88 & & \\
\hline MAS4 & & & 0.88 & & \\
\hline COL6 & & & & -0.72 & \\
\hline COL4 & & & & -0.69 & \\
\hline COL3 & & & & -0.67 & \\
\hline COL2 & & & & -0.59 & \\
\hline COL1 & & & & -0.58 & \\
\hline COL5 & & & & -0.51 & \\
\hline INC3 & & & & & -0.74 \\
\hline INC1 & & & & & -0.72 \\
\hline INC2 & & & & & -0.71 \\
\hline INC5 & & & & & -0.67 \\
\hline INC4 & & & & & -0.64 \\
\hline
\end{tabular}


Table 5: Cultural values at the individual level in Cameroon (in comparison with other African countries)

\begin{tabular}{|l|c|c|c|c|}
\hline & $\begin{array}{c}\text { Our } \\
\text { data* }\end{array}$ & $\begin{array}{c}\text { Hofstede's } \\
\text { Angola }\end{array}$ & $\begin{array}{c}\text { Hofstede's } \\
\text { Burkina Faso }\end{array}$ & $\begin{array}{c}\text { Hofstede's } \\
\text { Nigeria }\end{array}$ \\
\hline Power distance & 58 & 83 & 70 & 80 \\
\hline Uncertainty avoidance & 80 & 60 & 55 & 55 \\
\hline Individualism & 42 & 18 & 15 & 30 \\
\hline Masculinity & 70 & 20 & 50 & 60 \\
\hline Long term orientation & 69 & 15 & 27 & 13 \\
\hline
\end{tabular}

* Scores are ranging from 0 (very low) to 100 (very high).

Table 6: Cultural values according to the three main ethnic groups $(n=374)$ : mean, standard deviation and $F$ value.

\begin{tabular}{|l|c|c|c|c|}
\hline & $\begin{array}{c}\text { Bamiléké } \\
\text { and } \\
\text { Bamoun (n } \\
=140)\end{array}$ & $\begin{array}{c}\text { Douala, } \\
\text { Lundu and } \\
\text { Bassa } \\
(\mathrm{n}=127)\end{array}$ & $\begin{array}{c}\text { Fang and } \\
\text { Beti } \\
(\mathrm{n}=107)\end{array}$ & F value \\
\hline Power distance & $2.37(0.94)$ & $2.21(1.06)$ & $3.96(0.84)$ & $6.32^{*}$ \\
\hline $\begin{array}{l}\text { Uncertainty } \\
\text { avoidance }\end{array}$ & $4.14(0.63)$ & $3.93(0.79)$ & $3.65(0.83)$ & $13.03^{* *}$ \\
\hline Collectivism & $3.38(1.07)$ & $4.17(0.74)$ & $3.32(0.75)$ & $7.93^{*}$ \\
\hline Masculinity term & $3.43(1.13)$ & $2.58(1.12)$ & $4.02(1.04)$ & $11.67^{* *}$ \\
\hline $\begin{array}{l}\text { Long } \\
\text { orientation }\end{array}$ & $4.43(0.65)$ & $4.13(0.70)$ & $3.61(1.14)$ & $30.14 * *$ \\
\hline
\end{tabular}

$* * \rho<0.01 ; * \rho<0.05$ 
Table 7: Individual-Centered Market Segmentation according to the dimensions of the CVSCALE

\begin{tabular}{|c|c|c|c|}
\hline & \multicolumn{3}{|c|}{$\begin{array}{c}\text { Segment composition of three-cluster solution: mean and standard } \\
\text { deviation }\end{array}$} \\
\hline & $\begin{array}{c}\text { Segment } 1(\mathrm{n}=181 \\
49.1 \%)\end{array}$ & $\begin{array}{c}\text { Segment } 2(\mathrm{n}=98 ; \\
26.6 \%)\end{array}$ & $\begin{array}{c}\text { Segment } 3(\mathrm{n}=90 ; \\
24.4 \%)\end{array}$ \\
\hline $\begin{array}{l}\text { Long-term } \\
\text { orientation }\end{array}$ & $4.80(0.42)$ & $2.99(0.90)$ & $4.02(0.28)$ \\
\hline $\begin{array}{l}\text { Power } \\
\text { distance }\end{array}$ & $2.65(0.86)$ & $3.99(0.67)$ & $1.26(0.33)$ \\
\hline $\begin{array}{l}\text { Uncertainty } \\
\text { avoidance }\end{array}$ & $4.32(0.39)$ & $3.13(0.77)$ & $4.12(0.68)$ \\
\hline Masculinity & $3.18(1.16)$ & $4.35(0.95)$ & $2.11(0.50)$ \\
\hline Collectivism & $3.24(0.66)$ & $3.20(1.23)$ & $4.10(0.73)$ \\
\hline $\begin{array}{l}\text { Descriptive } \\
\text { variables }\end{array}$ & & & \\
\hline Age & 33.7 & 32 & 35.8 \\
\hline $\begin{array}{l}\text { Main ethnic } \\
\text { group }\end{array}$ & $\begin{array}{c}\text { Bamiléké and Bamoun } \\
=48.1 \%\end{array}$ & Fang and Beti $=58.2 \%$ & $\begin{array}{c}\text { Douala, Lundu and } \\
\text { Bassa }=50 \%\end{array}$ \\
\hline $\begin{array}{l}\text { Main spoken } \\
\text { language }\end{array}$ & English $=55.2 \%$ & French $=60.2 \%$ & French $=95 \%$ \\
\hline $\begin{array}{l}\text { Ratio of male } \\
\text { subjects }\end{array}$ & $56.4 \%$ & $63.3 \%$ & $52.2 \%$ \\
\hline
\end{tabular}




\section{References}

Bearden, W. O., Money, R. B., \& Nevins, J. L., 2006, A measure of long-term orientation: Development and validation. Journal of the Academy of Marketing Science, 34(3), 456-467.

Brislin, R. W., 1980, Expanding the role of the interpreter to include multiple facets of intercultural communication. International Journal of Intercultural Relations, 4(2), 137-148.

Churchill, G. A.,1979, A paradigm for developing better measures of marketing constructs. Journal of Marketing Research, XVI, 64-73.

De Mooij, M., \& Hofstede, G., 2010, The Hofstede model: Applications to global branding and advertising strategy and research. International Journal of Advertising, 29(1), 85-110.

De Mooij, M., \& Hofstede, G., 2011, Cross-cultural consumer behavior: A review of research findings. Journal of International Consumer Marketing, 23(3-4), 181-192.

DeVellis R. F. (2012) Scale Development: Theory and Applications (Vol. 26). $3^{\text {rd }}$ ed. Thousand Oaks: Sage.

Donthu, N. \& Yoo, B., 1998, Cultural Influences on Service Quality Expectations. Journal of Service Research, 1(2), 178-186.

Dorfman, P. W. \& Howell, J. P., 1988, Dimensions of national culture and effective leadership patterns: Hofstede revisited. Advances in International Comparative Management, 3, 127-50.

Furrer, O., Liu, B. S. C., \& Sudharshan, D., 2000, The relationships between culture and service quality perceptions basis for cross-cultural market segmentation and resource allocation. Journal of service research, 2(4), 355-371. 
Fornell, C., \& Larcker, D., 1981, Evaluating structural equation models with unobservable variables and measurement error. Journal of Marketing Research, 18(1), 39-50.

Hair J. F., Anderson R. E., Tatham R. L., et al. (1998) Multivariate Data Analysis. Upper Saddle River: Prentice Hall.

Hofstede, G., 1980, Culture's consequences: International differences in work-related values. Beverly Hills, CA: Sage.

Hofstede, G., 1991, Cultures and organizations. Intercultural cooperation and its importance for survival. Software of the mind. London: Mc Iraw-Hill.

Hofstede, G., 2001, Culture's Consequences. 2nd ed. Thousand Oaks, CA: Sage.

Hofstede, G., Hofstede, G. J., \& Minkov, M., 2010, Cultures and Organizations: Software of the Mind. 3rd ed. New York: McGraw-Hill.

Jöreskog, K. G. \& Sörbom D., 1993, LISREL 8: User's Reference Guide. Chicago: Scientific Software International, Inc.

Jyoti, J., \& Kour, S. 2017, Factors affecting cultural intelligence and its impact on job performance: Role of cross-cultural adjustment, experience and perceived social support. Personnel Review, 46(4), 767-791.

Kale, S. H., 1995, Grouping Euroconsumers: A Culture-based Clustering Approach, Journal of International Marketing, 3(3): 35-48.

Kale, S. H., \& Barnes, J. W., 1992, Understanding the Domain of Cross-Cultural Buyer-Seller Interactions, Journal of International Business Studies, 23(1), 101-132. 
Kamakura, W. A., \& Mazzon. J. A., 1991, Value Segmentation: A Model for the Measurement of Values and Value Systems. Journal of Consumer Research, 18(2), 208-218

Kamakura, W. A., \& Novak, T. P., 1992, Value-System Segmentation: Exploring the Meaning of LOV. Journal of Consumer Research, 19(1), 119-132.

Lenartowicz, T., \& Roth, K., 1999, A framework for culture assessment, Journal of International Business Studies, 30(4), 781-798.

Mattila, A. S., 1999, The role of culture and purchase motivation in service encounter evaluations. Journal of Services Marketing, 13(4/5), 376-389.

Morrison, A., \& Bergin-Seers, S., 2002, Pro-growth small businesses: learning 'architecture', Journal of Management Development, 21(5), 388-400.

Nunnally, J. C., \& Bernstein, I. H., 1994, Psychometric Theory, 3rd ed. New York: McGrawHill.

Patterson, P. G., \& Smith, T., 2001, Relationship benefits in service industries: a replication in a Southeast Asian context. Journal of services marketing, 15(6), 425-443.

Patterson, P. G., \& Smith, T., 2003, A cross-cultural study of switching barriers and propensity to stay with service providers. Journal of retailing, 79(2), 107-120.

Patterson, P. G., Cowley, E., \& Prasongsukarn, K., 2006, Service Failure Recovery: The Moderating Impact of Individual-Level Cultural Value Orientation on Perceptions of Justice. International Journal of Research in Marketing, 23(3), 263-277. 
Paul, P., Abhijit, R., and Kausiki, M., (2006), The impact of cultural values on marketing ethical norms: a study in India and the United States. Journal of International Marketing, 14(4), 2856.

Peter, J. P., 1979, Reliability: A review of psychometric basics and recent marketing practices. Journal of marketing research, 6-17.

Prasongsukarn, K., 2009, Validating the Cultural Value Scale (CVSCALE): A Case Study of Thailand. ABAC Journal, 29(2), 1-13.

Rummel, R. J., 1970, Applied Factor Analysis, Evanston, IL: Northwestern University Press.

Shackleton, V. J., \& Ali, A. H., 1990, Work-related values of managers: A test of the Hofstede model. Journal of cross-cultural psychology, 21(1), 109-118.

Sharma, P., 2010, Measuring personal cultural orientations: scale development and validation. Journal of the Academy of Marketing Science, 38(6), 787-806.

Smith, B. A., 2004, Relationship Management in the Sales Organization: An examination of leadership style and cultural orientation in sales manager and salesperson dyads. Doctoral dissertation, Drexel University.

Smith, P. B., \& Schwartz, S., 1997, Values. In: Handbook of cross-cultural psychology, edited by John W. Berry, Marshall H. Segall, \& Kagitcibasi Cigdem, Social behaviour and applications, Vol. 3, 2nd ed., Boston: Allyn \& Bacon, pp. 77-118

Soares, A., 2005, The influence of culture on consumers: Exploratory and risk taking behavior, Unpublished Doctoral Dissertation. Escola de Economica e Gestao. University of Minho. 
Soares, A., Farhangmehr M. \& Shoham A., 2007, Hofstede's dimensions of culture in international marketing studies, Journal of Business Science, 60, 277-284.

Sobol, K., 2008, The Global Consumer Culture': An Empirical Study In the Netherlands, Doctoral dissertation, Concordia University Montreal, Quebec, Canada.

Sondergaard, M., 1994, Research note: Hofstede's consequences: A study of reviews, citations and replications. Organization Studies, 15(3), 447-456.

Tinsley H. E. and Tinsley D. J. 1987, Uses of factor analysis in counseling psychology research. Journal of Counseling Psychology, 34(4), 414.

Trompenaars, F., \& Hampden-Turner, C., 1997, Riding the Waves of Culture: Understanding cultural diversity in business, Nicholas Brealy. London, England.

Yoo, B., \& Donthu. N., 1999, Cultural Orientation and Consumer Ethnocentrism. Proceedings of the 1999 Summer Marketing Educators' Conference of American Marketing Association.

Yoo, B., \& Donthu. N., 2002, The Effects of Marketing Education and Individual Cultural Values on Marketing Ethics of Students. Journal of Marketing Education, 24(2), 92-103.

Yoo, B., \& Donthu. N., 2005, The Effect of Personal Cultural Orientation on Consumer Ethnocentrism: Evaluations and Behaviors of U.S. Consumers toward Japanese Products. Journal of International Consumer Marketing, 18(1/2), 7-44.

Yoo, B., Donthu, N., \& Lenartowicz, T., 2011, Measuring Hofstede's five dimensions of cultural values at the individual level: Development and validation of CVSCALE. Journal of International Consumer Marketing, 23(3-4), 193-210. 